\title{
PHYSICAL APPEARANCE AND INTIMATE FRIENDSHIP IN ADOLESCENCE: A STUDY USING A PORTUGUESE COLLEGE STUDENT SAMPLE
}

\author{
Raul CoRdeiro \\ Polytechnic Institute, Portalegre, Portugal
}

\begin{abstract}
A group of students enrolled in the 12th year of education was asked to answer a direct application questionnaire containing the following measures: Intimate Friendship Scale (IFS) (Sharabany, 1994), The Self-Perception Profile for College Students (Neemann \& Harter, 1986) adapted for the Portuguese population (Ribeiro, 1994) and Family Social Notation Adapted Graffar, adapted from the original (Graffar, 1956). The values of Intimate Friendship were found to be higher for girls and the values of Perception of Physical Appearance were higher for boys.
\end{abstract}

Important aspects that today win more emphasis in the study of adolescence are related to the development of the capacity for establishment of intimate relationships and the perception of self-concept.

In studies by Sharabany (1994 and 2000), of adolescence and pre-adolescence the concept of intimate friendship, was structured in eight dimensions: Frankness and Spontaneity; Sensitivity and Knowing; Attachment; Exclusiveness; Giving and Sharing; Imposition; Common Activities and Trust and Loyalty. The same author developed several studies in this area using, as the base of his investigation, an evaluation scale, which was used in the present study.

We enhanced the importance of the concepts of perception of the body and selfconcept equally. The concept of the ideal body is important in relational satisfaction and in the adolescent's self-esteem. This representation or internalized image is intimately linked to the relationships that the adolescent maintains with the image of his/her body that others reflect to him/her.

Raul Cordeiro, Polytechnic Institute, Superior School of Nursing, Portalegre, Portugal. Appreciation is due to anonymous reviewers.

Please address correspondence and reprint requests to: Raul Cordeiro, Polytechnic Institute, Superior School of Nursing, Av. Santo António, 7301-901 Portalegre, Portugal. Phone: 351245300 430; Fax: 351245300 439; Email: <raulcordeiro@sapo.pt> 


\section{INVESTIGATION GOALS}

- To evaluate the perception of physical appearance in adolescents of both sexes;

- To evaluate the level of development of relationships of intimate friendship in adolescents of both sexes;

- To identify differences between the sexes in relation to the perception of physical appearance and the level of development of relationships of friendship.

\section{METHOD}

\section{Participants}

The study was carried out with a population of $N=318$ students, from two high schools. A total of 309 students ( $97,1 \%$ of the total of the population in the study), answered the questionnaire, being $49.5 \%(n=153)$ of school $\mathrm{A}$ and $50.5 \%$ $(n=156)$ of school B. Of the 309 students, $45 \%(n=139)$ were boys and $55 \%$ $(n=170)$ were girls. The median value of the participants' age was 18.04 years, with a standard deviation of 1.15, with the median values for boys (18.15) and girls (17.95) with standard deviations of 1.26 and 1.05 respectively.

\section{Measures}

Intimate Friendship Scale (IFS; Sharabany, 1994, 2000), validated by several studies (Eshel, Sharabany, \& Friedman, 1998; Floyd \& Voloudakis, 1999, Jones \& Dembo, 1989; Mayseless, Sharabany, \& Sagi, 1997; Mayseless, Wiseman, \& Hai, 1998; Sharabany, 1994, 2000), was applied in two forms: Intimate Friendship Scale 1 - My Best Boy Friend and Intimate Friendship Scale 2 - My Best Girl Friend. IFS is a Likert ordinal scale (values between 1 and 7) composed of 32 items, being 4 items for each one of the 8 dimensions (Alpha coefficients $=.95$ ).

The Self-Perception Profile for College Students (Neemann \& Harter, 1986), adapted for the Portuguese population (Ribeiro, 1994). In this study only seven (7) of the thirteen (13) subscales of the original scale were used: Intimate Friendships, Social Acceptance, Relationship with the Parents, Loving Relationships, Humour, Morality, Global Appreciation, in a total of 34 structured items using a Likert-type scale ordinal ranging from 1 to 4 (Alpha coefficients $=.89$ ).

Social Notation of the Family Scale - adapted by Graffar, adapted from the original scale (Graffar, 1956), with obtained results computed in five levels of social and economic class: high, high average, average, low and below average. 
Other variables were: school, sex, age, residence, number of enrolled years in the 12th year of education and repetitions before the 12th year of education. In the Portuguese education system, the 12th year of education is the year before university and it is frequently repeated for classification improvement that allows access to university. It is usual to remain two or more years in the 12th year of education trying to improve one's classification.

\section{RESULTS}

TABLE 1

Scores and Standard Deviation of Intimate Friendship - Results by SeX

\begin{tabular}{lccccc}
\hline & $n$ & Minimum & Maximum & $M$ & $S D$ \\
\hline Boys & 139 & 105.00 & 219.50 & 172.13 & 22.21 \\
Girls & 170 & 59.00 & 216.50 & 183.31 & 21.44 \\
\hline
\end{tabular}

TABLE 2

$t$-Test for the Dimensions of Intimate Friendship - Results Between SEXes

\begin{tabular}{lcl}
\hline Dimensions of Intimate Friendship & $t$ & $p$ \\
\hline Frankness and Spontaneity & -3.880 & $0.000^{* *}$ \\
Sensitivity and Knowing & -4.811 & $0.000^{* *}$ \\
Attachment & -6.106 & $0.000^{* *}$ \\
Exclusiveness & -1.281 & $\mathbf{0 . 2 0 1}$ \\
Giving and Sharing & -4.146 & $0.000^{* *}$ \\
Imposition & -3.161 & $0.002^{* *}$ \\
Common Activities & -2.621 & $0.009^{* *}$ \\
Trust and Loyalty & -3.256 & $0.001^{* *}$ \\
\hline
\end{tabular}

TABLE 3

$t$-Test for the Dimensions of Intimate FriendShip With the Best Boy Friend Results Between Sexes

\begin{tabular}{lcl}
\hline Dimensions of Intimate Friendship & $t$ & $p$ \\
\hline Frankness and Spontaneity & -3.176 & $0.002^{* *}$ \\
Sensitivity and Knowing & -3.401 & $0.001^{* *}$ \\
Attachment & -10.091 & $0.000^{* *}$ \\
Exclusiveness & -5.502 & $0.000^{* *}$ \\
Giving and Sharing & -4.225 & $0.000^{* *}$ \\
Imposition & -3.573 & $0.000^{* *}$ \\
Common Activities & -1.351 & $\mathbf{0 . 1 7 8}$ \\
Trust and Loyalty & -3.981 & $0.000^{* *}$ \\
\hline
\end{tabular}


TABLE 4

$t$-Test for the Dimensions of Intimate Friendship with the Best GiRl Friend - Results Between SeXes

\begin{tabular}{lcl}
\hline Dimensions of Intimate Friendship & $t$ & $p$ \\
\hline Frankness and Spontaneity & 3.210 & $0.001^{* *}$ \\
Sensitivity and Knowing & 4.355 & $0.000^{* *}$ \\
Attachment & 1.231 & $\mathbf{0 . 2 1 9}$ \\
Exclusiveness & 3.635 & $0.000^{* *}$ \\
Giving and Sharing & 3.100 & $0.002^{* *}$ \\
Imposition & 1.456 & $\mathbf{0 . 1 4 6}$ \\
Common Activities & 2.780 & $0.006^{* *}$ \\
Trust and Loyalty & 1.620 & $\mathbf{0 . 1 0 6}$ \\
\hline
\end{tabular}

TABLE 5

Scores and Standard Deviation Self-Concept Perception - Results by Sex

\begin{tabular}{lccccc}
\hline & $n$ & Minimum & Maximum & $M$ & $S D$ \\
\hline Boys & 139 & 62.00 & 126.00 & 98.68 & 13.74 \\
Girls & 170 & 54.00 & 125.00 & 94.79 & 13.28 \\
\hline
\end{tabular}

TABLE 6

Correlation Coefficient Between Perception of Physical Appearance and Intimate FRIENDSHIP - RESULTS BY SEX

\begin{tabular}{lcccccc}
\hline $\begin{array}{l}\text { Correlation Coefficient } \\
\text { Spearman }\left(r_{s}\right)\end{array}$ & $\begin{array}{c}\text { Boys } \\
(n=139)\end{array}$ & $\begin{array}{c}\text { Girls } \\
(n=170)\end{array}$ & \multicolumn{2}{c}{$\begin{array}{c}\text { Total } \\
(N=309)\end{array}$} \\
\hline & $r_{s}$ & $p$ & $r_{s}$ & $p$ & $r_{s}$ & $p$ \\
\hline $\begin{array}{l}\text { Perception of Physical Appearance / } \\
\text { Intimate Friendship }\end{array}$ & 0.113 & 0.186 & 0.026 & 0.737 & 0.108 & 0.059 \\
$\begin{array}{l}\text { Perception of Physical Appearance / } \\
\text { Intimate Friendship with best boyfriend }\end{array}$ & 0.080 & 0.347 & 0.057 & 0.459 & 0.102 & 0.074 \\
$\begin{array}{l}\text { Perception of Physical Appearance / } \\
\text { Intimate Friendship with best girlfriend }\end{array}$ & 0.104 & 0.223 & 0.026 & 0.734 & 0.082 & 0.149 \\
\hline
\end{tabular}

\section{DISCUSSION}

In this study the existence of relationships of intimate friendship in adolescence was found to be strongly influenced by sex.

It should not be forgotten that a development phase was being studied in which the expression of a stable sexual orientation emerges (heterosexuality), that naturally creates conditions for the expression of intimacy. 
A similar value was found for both sexes for relationships with girls. For the respondent girls, this finding can be related with an identification factor, with ideas and common feelings or even by similar socialization processes. For the respondent boys, the result suggests that those factors are more related to the defense of a position in relations with the opposite sex, from the perspective that the search for a special girl allows them, in this late phase of adolescence, to affirm their manliness, which is essential in the socialization process.

The values of Perception of the Physical Appearance are revealed to be more influential in a low feminine self-concept.

As for the association of values found among the main variables of the study, the association between Perception about the Physical Appearance and Intimate Friendship, was statistically significant for all participants.

\section{REFERENCES}

Eshel, Y., Sharabany, R., \& Friedman, U. (1998). Friends, lovers and spouses: Intimacy in young adults. British Journal Social of Psychology, 37, 41-57.

Floyd, K., \& Voloudakis, M. (1999) Affectionate behaviour in adult platonic friendships. Human Communication Research, 25 (3), 341-369.

Graffar, M. (1956). Une méthode de classification sociale d’échantillons de population. Courier, 6, 455.

Jones, G. P., \& Dembo, M. H. (1989). Acts and sex role differences in intimate friendships during childhood and adolescence. Merrill Palmer Quarterly, 35, 445-462.

Mayseless, O., Sharabany, R., \& Sagi, A. (1997). Attachment concerns of mothers as manifested in parental, spousal, and friendship relationships. Personal Relationships, 4, 255-269.

Mayseless, O., Wiseman, H., \& Hai, I. (1998). Adolescents relationships with father, mother, and same-sex friend. Journal of Adolescent Research, 13, 101-123.

Neeman, J., \& Harter, S. (1986). Manual for the Self-Perception Profile for College Students. Denver: University of Denver.

Ribeiro, J. L. P. (1994). Adaptação do the self-perception profile for college students à população portuguesa como instrumento para ser utilizado no contexto da psicologia da saúde. In: L. Almeida, I. Ribeiro. (Eds.) Avaliação Psicológica: Formas e contextos. Braga: APPORT,129138.

Sharabany, R. (1994). Intimate friendship scale: Conceptual underpinnings, psychometric properties and construct validity. Journal of Social and Personal Relationships, 11, 449-469.

Sharabany, R. (2000). Intimacy in preadolescence: Issues in linking parent and peers, theory, culture, and findings. In K. A. Kerns, J. M. Contreras, \& A. M. Neal-Barnett (Eds.), Family and peers: Linking two social worlds. Westport, Connecticut: Praeger Publishers. 
